\title{
HUBUNGAN BODY IMAGE DAN IMAGINARY AUDIENCE DENGAN KEPERCAYAAN DIRI PADA REMAJA DI SMA PANCA BUDI MEDAN
}

\author{
Aminda Tri Handayani \\ Universitas Muslim Nusantara Al-Washliyah Medan \\ aminda_trihandayani@yahoo.com
}

\begin{abstract}
Abstrak
Penelitian ini bertujuan untuk mengetahui Hubungan Body Image dan Imaginary Audience dengan kepercayaan diri pada Peserta Didik di SMA Yayasan Perguruan Panca Budi. Dalam hal ini Body Image dan Imaginary audience sebagai variabel independen, dan kepercayaan diri sebagai variabel dependen.kepercayaan diri merupakan salah satu faktor penting menggapai kesuksesan dalam melakukan segala sesuatunya. Awal Kesuksesan dimulai dari masa remaja dimana salah satu tahap dalam kehidupan manusia yang merupakan masa transisi dari masa kanak-kanak menuju masa dewasa. Pada tahap ini remaja akan mengalami perubahan baik dari segi fisik, kognitif dan psikososial. Sejalan dengan perubahan fisik, remaja cenderung mengembangkan kepedulian yang tinggi terhadap perubahan fisiknya. Hal-hal yang menyebabkan remaja tidak dapat percaya diri sendiri secara fisik seperti tinggi badan, berat badan, ukuran tubuh, bahkan raut wajah atau disebut juga dengan body image. Remaja sendiri sangat peka terhadap penilaian dirinya dan merenung perihal bagaimana wajahnya, apakah orang lain menyukai wajahnya serta selalu menggambarkan dan mengembangkan seperti apa tubuhnya dan apa yang diiginkan dari tubuhnya atau lebih dikenal dengan imaginary audience. Cara pandang remaja terhadap keadaan fisiknya ini akan mempengaruhi rasa kepercayaan diri. Kepercayaan diri adalah suatu hal yang dapat membuat kita mengeluarkan segenap kemampuan atau potensi terbaik kita. Penelitian ini mengambil lokasi di SMA Yayasan Perguruan Panca Budi Jl. Gatot Subroto-Medan. Metode penelitian yang digunakan dalam penelitian ini adalah metode kuantitatif dengan sampel 2 kelas dari kelas VIII SMP yang masing-masing kelas berjumlah 30 orang. Dengan demikian data yang diambil berupa angket untuk skala alat ukur body image dan imaginary audience dan kepercayaan diri dengan menggunakan analisis regresi. Analisis data dilakukan dengan menggunakan SPSS 21 for windows.
\end{abstract}

\begin{abstract}
This study aims to determine the relationship of Body Image and Imaginary Audience with confidence in Students in High School Foundation Panca Budi Foundation. In this case the Body Image and Imaginary audience as independent variables, and selfconfidence as a dependent variable. Confidence is one important factor in achieving success in doing things. Beginning Success begins from adolescence where one of the stages in human life which is a transition from childhood to adulthood. At this stage teenagers would experience changes both in terms of physical, cognitive and psychosocial. In line with physical changes, adolescents tend to develop a high awareness of the physical changes. Things that cause teens cannot be physically confident like height, weight, body size, even facial expression or also called body image. Teenagers themselves were very sensitive to his assessment and reflect on how his face, whether others like his face and always describe and develop what his body
\end{abstract}


and what was wanted from his body or better known as the imaginary audience. The way the teen's view of his physical state would affect his sense of confidence. The Confidence was something that can make us take out all our potential or potential. This research took place in Senior High School Panca Budi Jl. Gatot Subroto-Medan. The research method was used in this study was a quantitative method with a sample of 2 classes of class VIII SMP which each class amounted to 30 people. Thus the data taken in the form of a questionnaire to scale the measuring tool of the image body and imaginary audience and confidence by using regression analysis. Data analysis was done by using SPSS 21 for windows ..

Keyword: body image, imaginary audience, self confidence.

\section{PENDAHULUAN}

Setiap manusia terlahir dengan memiliki rasa percaya diri, namun tidak semua orang bisa memiliki rasa percaya diri yang tinggi. Demikian juga dengan rasa percaya diri yang dimiliki seorang remaja, dimana rasa percaya diri ini sebenarnya merupakan salah satu indikator kecerdasan emosional yang berhubungan dengan kemampuan untuk memahami kelebihan dan kekurangan yang dimilikinya.

Menurut Hambly (1991) kepercayaan diri merupakan keyakinan yang dimiliki dalam menangani segala situasi. Seseorang yang kurang mampu menghadapi situasi yang ada, maka seseorang tersebut akan merasa kurang percaya diri. Rasa kurang percaya diri inilah yang menyebabkan individu akan berperilaku negatif, pesimis dan tidak mengakui dirinya sendiri.

$$
\text { Masalah penampilan }
$$

menjadi hal yang penting bagi remaja untuk mengembangkan citra individu mengenai gambaran tubuhnya sehingga berpengaruh terhadap tingkat kepercayaan diri individu tersebut. Remaja menganggap mempunyai tubuh langsing dan ideal akan menjadikannya pusat perhatian dan membuat remaja tersebut menjadi penuh percaya diri. Remaja yang mempunyai rasa percaya diri akan tumbuh menjadi pribadi yang kuat, sehat dan tangguh.

Banyak faktor-faktor yang membuat individu kurang percaya diri salah satunya adalah penampilan fisik. Seperti yang diungkapkan oleh Mangunghardjana (1987) bahwa faktor yang mempengaruhi kepercayaan diri salah satunya adalah faktor fisik. Dimana seseorang akan lebih percaya diri bila fisiknya sempurna. Salah satnya adalah bagaimana cara individu tersebut mempersepsikan tenang tubuhnya atau penampilan fisiknya.ketika individu tersebut mempersepsikan tentang tubuhnya positif maka akan meningkatkan kepercayaan diri individu tersebut dan sebaliknya ketika individu mempersepsikan tubuhnya negatif maka kepercayaan diri individu tersebut akan cenderung rendah. Ditambahkan oleh Surya (2009) menyatakan bahwa seseorang akan percaya diri ketika orang tersebut merasa puas melihat bentuk tubuhnya, maka body image yang terbentuk pun menjadi positif. Sebaliknya , jika seseorang memandang tubuhnya tidak ideal seperti wajahnya kurang menarik, badannya terlalu gemuk atau terlalu kurus dan sebagainya maka orang tersebut menjadi sibuk memikirkan kondisi fisiknya, sehingga body 
image yang terbentuk menjadi negatif dan dapat dikatakan orang tersebut tidak memiliki kepercayaan diri.

Salah satu bagian perkembangan kognitif masa kanakkanak yang belum sepenuhnya ditinggalkan oleh remaja adalah kecenderungan cara berpikir abstrak imaginary audience. Imaginary audience menggambarkan peningkatan kesadaran remaja yang tampil pada keyakinan mereka bahwa orang lain memiliki perhatian yang amat besar terhadap diri mereka sendiri, gejalanya mencakup berbagai perilaku untuk mendapatkan perhatian (keinginan agar kehadirannya diperhatikan, disadari oleh orang lain, dan menjadi pusat perhatian) (Santrock, 2007). Menurut Elkind (1984), remaja juga menyatakan kesadaran akan imaginary audience melalui strategi interaksi dengan teman sebaya yang tujuannya adalah untuk menyatakan atau menyembunyikan informasi pribadi.

Remaja seringkali merasa bahwa orang lain memperhatikan dirinya seperti sama halnya dengan dirinya sendiri. Remaja akan melihat bagaimana reaksi orang lain terhadap penampilan atau perilaku mereka.

Berdasarkan observasi

penulis, terdapat beberapa perilaku yang sering dimunculkan oleh remaja, yaitu kurang berani untuk maju di depan kelas, saling melempar tugas kepada temannya jika disuruh maju oleh gurunya di depan kelas. Berjalan kikuk dan canggung di depan orang-orang yang belum di kenalnya atau tempat asing. Merasa malu untuk tampil karena tidak percaya diri dengan penampilannya dan merasa semua orang akan memperhatikannya. Jika

ada sebagian temannya yang berani tampil di muka umum, maka teman-teman yang lain akan menyoraki. Bagi remaja putri lebih memilih ditemani oleh temannya jika ingin ke toilet. Suka sekali bercermin dan lain-lain. Berdasarkan berbagai peristiwa atau pengalaman tadi, bisa dilihat gejala-gejala tingkah laku seseorang yang menggambarkan adanya rasa percaya diri atau tidak.

Dari latar belakang permasalahan di atas, maka dianggap perlu melakukan penelitian "Hubungan Body image dan Imaginary audience Terhadap Kepercayaan Diri pada Peserta Didik di SMA Yayasan Perguruan Panca Budi : untuk dapat melihat seberapa besar hubungan antara body image dan imaginary audience yang ada pada diri remaja berpengaruh besar terhadap kepercayaan diri nya.

\section{METODE}

Tempat penelitian ini
dilakukan di SMA Yayasan
Perguruan Panca Budi Jl. Gatot
Subroto - Medan. Metode
penelitian ini adalah kuantitatif. Oleh
karena itu populasi yang diambil
adalah remaja seluruh kelas X SMA
Yayasan Perguruan Panca Budi.
Sampel penelitian ini menggunakan
Purposive Sampling ,maka sampel
yang diambil hanya 2 kelas
dengan jumlah masing-masing 30
peserta didik.
Dengan demikian varaibel
dalam penelitian ini terdapat 2
variabel, variable independen (bebas)
adalah body image dan imaginary
audience, variable dependen (terikat)
adalah kepercayaan diri. Dari
penjelasan diatas desain penelitian
yang digunakan adalah desain
korelasi (asosiatif).


Metode yang digunakan untuk mengumpulkan data dalam penelitian ini adalah metode skala.. Dalam penelitian ini disusun tiga skala untuk mengumpulkan data yaitu Skala Body image diukur menggunakan skala yang dikembangkan berdasarkan aspekaspek yang mempengaruhi body image menurut Cash (2002), yaitu Appearance evaluation, Appearance orientation, Body area satisfaction, Overweight preoccupation, Selfclassified weight. Variable imaginary audience diukur menggunakan skala imaginary audience disusun oleh Lapsley (1988) yang telah dimodifikasi oleh peneliti yang terdiri atas 30 aitem. Variable kepercayaan diri diukur menggunakan skala yang dikembangkan berdasarkan aspekaspek yang mempengaruhi kepercayaan diri menurut Lauster (Ghufron, 2011), yaitu keyakinan akan kemampuan diri , optimis, objektif, bertanggung jawab, rasional.

Berdasarkan hasil analisis pada, maka dapat diketahui bahwa pada bagian kedua output (kolom Sig. (2-tailed)) pada kolom kepercayaan diri bernilai 0.001 (lebih kecil dari 0.05) maka $\mathrm{H} 0$ di tolak dan $\mathrm{H}_{\mathrm{a}}$ diterima. Hal ini berarti terdapat hubungan yang positif antara body image dengan kepercayaan diri siswa.

Berdasarkan hasil analisis pada, maka dapat diketahui bahwa pada bagian kedua output (kolom Sig. (2-tailed)) pada kolom kepercayaan diri bernilai 0.004 (lebih kecil dari 0.05) maka $\mathrm{H} 0$ di tolak dan $\mathrm{H}_{\mathrm{a}}$ diterima. Hal ini berarti terdapat hubungan yang positif antara imaginary audience dengan kepercayaan diri siswa.

\begin{abstract}
Berdasarkan tabel di diketahui bahwa besarnya hubungan antara body image dan imaginary audience terhadap kepercayaan diri siswa yang ditunjukkan dengan koefisien korelasi adalah 0.565, hal ini menunjukkan pengaruh yang sedang.Sedangkan, kontribusi atau sumbangan secara simultan variabel body image dan imaginary audience terhadap kepercayaan diri adalah $0.319(31,9 \%)$ sedangkan 0.681 $(68,1 \%)$ ditentukan oleh variabel yang lain.

Selanjutnya, juga diperoleh nilai probabilitas (Sig. $F$ change) $0.006<0.05$ maka keputusan yang diambil adalah Ha diterima dan $\mathrm{H} 0$ ditolak yang artinya terdapat hubungan yang signifikan antara body image dan imaginary audience terhadap kepercayaan diri siswa.
\end{abstract}

\section{HASIL DAN PEMBAHASAN}

Seperti yang dikemukakan oleh Santrock (2001) bahwa penampilan fisik atau body image merupakan penyumbang yang kuat pada harga diri dan kepercayaan diri seseorang. Body image seseorang merupakan suatu evaluasi terhadap aspek- aspek fisiknya.

Remaja di SMA Perguruan Yayasan Panca Budi, menunjukan bahwa ketika diberikan pertanyaan mengenai apa yang tidak disukai dari diri meraka sendiri, hanya sedikit yang mengatakan akan halhal yang berhubungan dengan kemampuan mereka dan mereka cenderung menjawab hal-hal mengenai penampilan fisik mereka. Remaja berusaha memberikan penampilan sebaik mungkin termasuk penampilan fisik. Perhatian 
yang besar terhadap diri sendiri merupakan minat yang kuat pada remaja.

Konsep egosentrime remaja merupakan hal yang berkaitan dengan imaginary audience, karena imaginary audience merupakan salah satu aspek dalam egosentrisme remaja. Egosentrisme sendiri merupakan salah satu dari perkembangan kognitif masa kanakkanak yang belum sepenuhnya ditinggalkan oleh remaja.

Dengan memiliki imaginary audience yang positif, individu akan cenderung berpikir positif akan dirinya. Hasil penelitian yang dilakukan di perguruan Yayasan Panca Budi, menunjukan bahwa imaginary audience remaja di Panca Budi memiliki pengaruh yang besar terhadap perilaku dan kepercayaan diri mereka. Hal tersebut sesuai dengan penelitian yang dilakukan oleh Elkind dan Bowen (dalam Goossens, et.al, 2002) bahwa terdapat korelasi yang sangat tinggi antara imaginary audience dengan konsep diri, termasuk didalamnya adalah kepercayaan diri. 2002) . Penilaian yang diberikan oleh orang lain akan mempengaruhi perasaan dan rasa percaya diri remaja. Penilaian orang lain terhadap diri remaja selanjutnya akan mengembangkan persepsi tentang bagaimana orang lain memandang dirinya, sehingga dapat membuat individu melakukan perbandingan sosial dan akan berpengaruh terhadap rasa percaya diri remaja tersebut.

\section{KESIMPULAN}

Berdasarkan hasil analisis data, temuan dan pembahasan peneltiian maka dapt diambil kesimpulan sebagai berikut :

1. Terdapat hubungan yang positif antara body image dengan kepercayaan diri siswa.pada bagian kedua output (kolom Sig. (2-tailed)) pada kolom kepercayaan diri bernilai 0.001 (lebih kecil dari 0.05) maka $\mathrm{H}_{0}$ di tolak dan $\mathrm{H}_{\mathrm{a}}$ diterima. Hal ini menunjukkan bahwa semakin positif body image remaja maka semakin tinggi tingkat kepercayaan diri remaja

2. Terdapat hubungan yang positif antara imaginary audience dengan kepercayaan diri siswa. bahwa pada bagian kedua output (kolom Sig. (2-tailed)) pada kolom kepercayaan diri bernilai 0.004 audience terhadap kepercayaan diri siswa diperoleh nilai probabilitas (Sig. $F$ change) $0.006<0.05$ maka keputusan yang diambil adalah Ha diterima dan $\mathrm{H}_{0}$ ditolak yang artinya semakin positif body image dan imaginary audience pada ermaja secara bersama-sama semakin meningkatkan kepercayaan diri remaja. dan $\mathrm{H}_{\mathrm{a}}$ diterima. Hal ini berarti bahwa semakin positif imaginary audience remaja maka akan semakin tinggi kepercayaan diri remaja.

3. Terdapat hubungan yang signifikan antara body image dan imaginary Perkembangan Suatu Pendekatan Sepanjang Rentang Kehidupan. Edisi

\section{DAFTAR PUSTAKA}

Diane E. Papalia, et. Al (2008). Human Development (Psikologi 
Perkembangan). Jakarta; Kencana

Elkind, David H. 2004. How to Do Character Education. Artikel yang diterbitkan pada bulan September/Oktober 2004.

Hambly, K. 1991. Psikologi Populer : Bagaimana Meningkatkan Rasa PercayaDiri. Alih Bahasa : F.X Budiyanto. Jakarta : ARCAN

Hurlock, E. B. 1990. Psikologi Perkembangan. Alih Bahasa : Istiwadayanti

1999.

Psikologi Perkembangan : Suatu Pendekatan Sepanjang Rentang Kehidupan. Terjemahan : Dra. Istiwidayanti. Jakarta : Erlangga (Edisi Kelima)(lebih kecil dari 0.05) maka $\mathrm{H}_{0}$ di tolak (2008) . Psikologi 5 .Surabaya. PT. Gelora Aksara

Pratama Erlangga.

Marita, Gita A.D \& Yuliadi, istar \&Karyanata, NA, (2014). Hubungan antaraBody image dan Imaginary audien cedengan Kepercayaan Diri pada Siswi Kelas X SMA Negeri 2 Nganjuk.

Papalia, Olds, \& Feldman. (2001). Human Development (9th ed). New York: McGraw Hill (2008). Human

Yuliadi., 2013. Hubungan antara Body image dan Imaginary audience dengan Kepercayaan Diri pada SMK Negeri 2 Manado. Universitas Manado. Jurnal Ilmiah Psikologi Candrajiwa Volume 1 Nomor 4. Hal: 11
Development. Terjemahan oleh A.K. Anwar. 2008. Jakarta: Prenada Media Group.

Putri, R.L \& Hadi,Ch, (2007) Bagaimana memahami seorang diri remaja http://www.fpsi.unair.ac.id, diperoleh tanggal 17 februari 2008). Priyatno., 2011. Buku Saku SPSS Analisis Statistik Data (lebih Cepat, Efisien dan Akurat). Yogyakarta. Penerbit Mediakom

Rini, J.F (2002) . Memupuk Rasa Percaya Diri, http://digilib.itb.ac.id, diperoleh tanggal 17 Februari 2008.

Sarwono,W.S (2003). Psikologi Remaja.edisi 6. Jakarta : Raja Grafindo Persada

Santrock, J.W ( 1999). Life Span Development ( terjemahan ). Boston: Mc Graw Hill.

Soetjiningsih (2004). Buku Ajar Tumbuh Kembang Remaja Dan Permasalahannya. Jakarta : Sagung Seto

Sugiono., 2009.Metode Penelitian Pendidikan Pendekatan Kuantitatif, Kualitatif dan $R \& D$. Bandung. Penerbit Alfabeta

Yusuf., S., 2007. Psikologi Perkembangan Anak dan Remaja. Bandung. P.T. Remaja Rosdakarya 